UDC 372.881.1

DOI https://doi.org/10.24919/2308-4863/42-3-26

Oksana TYMOFYEYEVA,

orcid.org/0000-0001-6645-5604

PhD in Pedagogy, Associate Professor,

Associate Professor at the Department of Humanities

Danube Institute of National University "Odessa Maritime Academy" (Izmail, Odesa region, Ukraine) tymofoksana@gmail.com

\title{
LISTENING FOR SPECIFIC PURPOSES IN THE MARITIME ENGLISH TEACHING PROCESS
}

\begin{abstract}
The article is concerned with the listening for specific purposes skills as the invariant of the listening for general purposes. Listening differs from hearing at least by attention paid to the physical process. The types of listening and specific features of them have been described and analyzed. The research defines the difference between English for general and specific purposes in the terms of applied listening skills. The author examines the stages of listening, different classifications according to the intentions, purpose, and mode. The article investigates the requirements to the listening from the point of the English for specific purposes as Maritime English is considered to be the subtype of it. The common and variable features of both spheres of English are highlighted. The double nature of the communication aboard vessels has been outlined. The author suggests the general overview of the Maritime English usage situations aboard the ship comprising the Navigation and Engineering departments. The matching of the types of listening and Maritime English utilization aboard the ship has been done. The study states what exact subtypes of listening should be applied in every situation, thus allowing choosing precisely authentic listening material by using CALL (Computer Assisted Language Learning) namely through the World Wide Web. The principles of preparing materials for listening are relevance, transferability/ applicability and task orientation. The author describes the world video sharing platform YouTube as the tool for material and developing listening for specific purposes skills of cadets, future marine officers. The YouTube as a means of real context and language environment enhances the learning process and cadets' motivation. The variants of stages of listening lesson have been described.
\end{abstract}

Key words: Maritime English, listening for specific purposes, YouTube.

Оксана ТИМОФЕЕВА, orcid.org/0000-0001-6645-5604 кандидат педагогічних наук, доцент, доиент кафедри гуманітарних дисииплін Дунайського інституту Наиіонального університету «Одеська морська академія» (Ізмаїл, Одеська область, Україна) tyтоfoksana@gmail.com

\section{СЛУХАННЯ ЗАДЛЯ КОНКРЕТНИХ ЦІЛЙ ПІД ЧАС ВИКЛАДАННЯ МОРСЬКОї АНГЛІЙСЬКОї МОВИ}

Стаття присвячена навичкам слухання задля конкретних изілей як інваріанту слухання для загальних иілей. Слухання відрізняється від процесу «чути» увагою, яка приділяється цььому фізичному прочесу. У статті описано та проаналізовано типи прослуховування та їх специффічні особливості. Авторка визначає різницю між англійською мовою для загальних та конкретних иілей у контексті навичок прослуховування. Розглядаються етапи прослуховування, різні класифікаџії відповідно до намірів, мети та засобу. У статті досліджуються вимоги до прослуховування з точки зору англійської мови для конкретних иілей, оскільки морська англійська вважається підтипом иієеі мови. Висвітлено загальні та відмінні риси обох сфер англійської мови. Наведено подвійний характер комунікації на борту морських суден. Авторка пропонує узагальнену класифікаџію ситуацій з використанням морської англійської мови на борту судна, щуо використовується навігаційним та інженерним відділами. Здійснено співвіднесення типів прослуховування та використання англійської мови на борту судна. У кожній ситуації необхідно застосовувати конкретні підтипи прослуховування. Для навчання необхідно підбирати автентичний матеріал. За допомогою комп'ютерних технологій та Інтернет-ресурсів викладачі морської англійської можуть створювати такий матеріал. Принциипами підготовки матеріалів для прослуховування є релевантність, передача / придатність та орієнтація на завдання. Автор описує світову платформу для обміну відео “ҮоиТиье” як інструмент для накопичення матеріалу та розвитку навичок прослуховування для конкретних иілей курсантів майбутніх морських офіцерів. "ҮоиТиье” як засіб реального контексту та мовного середовища покращує процес навчання та підвищує мотивацію курсантів. Описано варіанти проведення етапів уроку прослуховування.

Ключові слова: морська англійська, навички прослуховування для конкретних цілееи, “ҮоиТиве”. 
Shipping industry requires qualified and competent seafarers and all concerned. The communicative competence as the ability to cooperate efficiently is considered to be one of the utmost important due to the vital necessity of this skill. The knowledge of academic subject is not sufficient for professional requirements; the communication skills should be gained in order to enhance the cadets', future marine officers' prospects for employment.

Problem stating. The goal of communication is to convey the message accurately. Ineffective communications in various spheres of our lives can lead to misunderstandings arising life-threatening consequences. In the world of international shipping, as Winbow (2002) states, including many countries seafarers sailing on ships trading with all the world, effective communication among them on board and between ship and shore has enormously importance. The unambiguous message is the keystone for safe navigation and operation of ships. The communication process comprises speaking (code and send message) and listening (decode and aware the meaning of it). Listening is the only way to receive message and a fundamental ability to acquire foreign language. In case of international shipping industry English is the lingua franca of this field.

The study aims at researching listening for specific purpose skills in the field of Maritime English. The objectives of research are to investigate the areas of listening aboard the ship and match them with the types of listening, in addition the ways to improve the listening skills of the cadets, future merchant marine officers.via the utilization of the YouTube.

Listening is a crucial part of the communication process, it is the media for it. The importance of listing skills is confirmed by the recent research of the language acquisition process (Renukadevi, 2014), stating that we acquire $45 \%$ of language and information through listening, $30 \%$ via speaking, the rest $25 \%$ are obtained through reading and writing. According to Brown listening is a spoken or written response from the student that indicates correct (or incorrect) auditory processing. He defines listening as a complex activity, and the cadets can comprehend what they hear by activating their prior knowledge. (Brown, 2004). Listening skills are essential for learning since they enable students to acquire insights and information, and to achieve success in communicating with others in everyday and professional environment (Walberg, 2004)

Results and Discussions. The language teaching process at Maritime higher institutions based on IMO Model Course 3.17 comprises English for general purposes, usually the first year of study and
English for specific purposes, namely Maritime English. Maritime English implies its specific linguistic knowledge and communication skills in order to accomplish specific needs in a particular professional field (Orr, 1998). The curriculum of Maritime English is content-based with the focus on subject matter and authentic materials. The communicative skills of both subtypes of the language (English for general purposes and English for specific purposes) differ slightly due to the sphere of application of the language at sea. Nonetheless the cadets should know the variety of listening types and their skills of this communicative competence area are to be trained. The appropriate usage of listening strategies in professional life depends on sphere and purpose of the required skills.

Listening is a multistage processing of information. The stages are hearing or receiving (the response caused by sound waves stimulating the sensory receptors of the ear and brain responds to stimuli selecting a few to be perceived, it is known as attention), understanding (analysis and interpretation of the selected stimuli, symbols and intended meaning of them and context); remembering (add the selected and interpreted meaning to own memory); evaluating (determine the quality of the message from the point of view of facts, opinion, own experience, bias or prejudice), and responding (process is completed through verbal and/or nonverbal feedback and the sender may determine the degree of success in transmitting the message) (Bite, 2013). The types of listening are classified according to the intention, mode of delivery, purpose, and environment. Brown (2004) distinguishes 6 types of listening according to the intention of listing: 1) informational (it is used in most cases of our live; it concerns the receiving and understanding the message); 2) selective (it applies only to specific information); 3) active (it requires attention and active response; the information is apprehended to the full extend); 4) critical (listener should evaluate the speaker's information critically; applied for group discussions, briefings); 5) appreciative (the aim is to encourage the speaker, information is received for enjoyment); 6) evaluative (the task of listener is to evaluate the information for significance, unbiased). This classification is applicable mostly in the sphere of English for general purposes.

The reason of listening can identify the engaged type of it. Wilson's classification is categorized as follows: 1) listening for gist (for general idea of the message); 2) listening for specific information (for specific part of the message with ignorance of the rest information); 3) listening in detail (for accurate listening and precise understanding of the message); 
4) inferential listening (the speaker and his/her feelings are the aim) (Wilson, 2019).

Listening process can be classified according to the purpose of it. I.S.P. Nation and J. Newton (2009) distinguish some types of listening as follow: 1) Oneway listening typically associated with the transfer of information (transactional listening). 2) Two-way listening typically associated with maintaining social relations (interactional listening).

Three basic of modes are defined by V. Bite (2013): 1) Active or Reflective Listening (the listener takes active position with supporting and feedback, clarifying information and paraphrasing, aiming at empathy, acceptance and assistance); 2) Passive or Attentive Listening (the aim is the other person's point of view, attentive and assuming listener without verification of information); 3) Competitive or Combative Listening (the aim is to promote the point of view of listener without attempts to understand the speaker).

The two spheres of English (English for general purposes and English for specific purposes) apply different types of listening. In every day life and social language environment all above mentioned types can be identified. In case of professional language environment some of the types (reflective, appreciative) are inappropriate whereas another types (listening for details, critical) are in urgent demand. Next point of difference between two types of listening is additional skills and knowledge required in the field of English for specific purposes. They require not less than pre-intermediate level of language as the material of the course, vocabulary, grammar and discourse structure, is far beyond the social topics. The cadets should know strategies of both spheres of the English language. Furthermore Maritime English as the working language of international shipping industry requires deep knowledge and efficient use of listening strategies inherent in English for specific purposes.

The Ukrainian National Curriculum for Universities of ESP (2005) defines professional language proficiency in listening at various matters: overall listening comprehension (understand the main idea of speech and follow extended speech in terms of professional or academic environment); interaction between native speakers (follow the main points of the speech). In case of international shipping industry the seafarers do not always deal with the native speakers. The ship's crews are multinational and multilingual in their nature. Consequently the future marine officers are to be able to understand various accents and speech speed. Next matters of National Curriculum for Universities of ESP are participation in a live audience (follow the essentials of lectures, conferences which are complex in terms of language); announcements, messages and instructions (understand and follow precise details); media and recordings (follow the message and identify the speaker's attitude and point of view).

The researcher Morley (Morley, 2001) suggests four perspectives as four modes of listening and language instruction: 1) listening and repeating; 2) listening and answering comprehension questions; 3) task list; 4) interactive listening. The fourth one is relevant for Maritime English learning process.

Vandergrift and Goh (2012) identifies the following core comprehension skills of English for specific purposes that can be used separately or in combination by the effective listener in order to achieve his/ her goals of listening: 1) Listen for details: understand and identify specific information; 2) Listen for main ideas: understand and summarize key points in a text (text can be defined as any discourse); 3) Listen for global understanding and identify the gist of the message; 4) Listen and infer: fill in the gaps in one's understanding by using knowledge about the language forms and use, and relevant prior knowledge; 5) Listen and predict: anticipate what one will hear; 6) Listen selectively: pay attention to specific parts of the message by ignoring other parts. The cadets should be aware of the usage of the linguistic and contextual cues to avoid any interference of receiving the information. A further question for consideration is relevance of the chosen information; the cadets should train the skill of selecting required items. Moreover the ESP Listening has interactive or bidirectional nature and the cadets should know the subskills of general purposes listening relating to turn-giving and turn-taking cues, recognizing, checking understanding, seeking clarifications and asking for more information.

The STCW requirements concerning level of the English language for the marine officers can be summarized as sufficient knowledge of this language in oral and written form for efficient performing of duties. The double nature of the English language usage aboard the ship should be underlined: on-duty communication and off-duty communication activities as the ship is a temporary place of work and live in. The part of life of seafarers aboard the ship can be characterized as social communicative competence: off-duty activities imply the communication on general topics, sharing interests, hobbies, families, future prospects, etc. Whereas the on-duty communication activities are strictly defined by the IMO (STCW as the standard of the requirements and competences for the seafarers of all positions and ranks) regulations and SMS (Safety Management System) of every shipping company all over the world. Two departments 
of merchant ships, Navigation and Engineering, use English unevenly due to their duties and connections with external parties of the shipping process. General and brief overview of the English language usage on board can be presented as follows (in order of coincidence of two departments):

\begin{tabular}{|l|l|}
\hline \multicolumn{1}{|c|}{ Navigation Dept. } & \multicolumn{1}{c|}{ Engineering Dept. } \\
\hline $\begin{array}{l}\text { 1. Watchkeeping procedures, } \\
\text { routine works and operations: } \\
\text { orders, commands, instructions }\end{array}$ & $\begin{array}{l}\text { 1. Watchkeeping procedures, } \\
\text { routine works and operations: } \\
\text { orders, commands, instructions }\end{array}$ \\
\hline 2. Safety, security, emergency & 2. Safety, security, emergency \\
\hline $\begin{array}{l}\text { 3. Port Operations (cargo } \\
\text { operations, PSC, inspections } \\
\text { and surveys) }\end{array}$ & $\begin{array}{l}\text { 3. Port operations (bunker, } \\
\text { supply) }\end{array}$ \\
\hline $\begin{array}{l}\text { 4. Radio Communication (ship } \\
\text { to ship, ship to shore) }\end{array}$ & $\begin{array}{l}\text { 4. Repair works (aboard and in } \\
\text { repair yards) }\end{array}$ \\
\hline
\end{tabular}

This general overview of Maritime English situations is suggested by the author and opened for further discussion, specification and detailing by Maritime English educators. Matching the above situations and types of listening according to Vandergrift and Goh classification the following can be appropriate:

1) Listen for main ideas is the starting point for any listening activities together with Listen for global understanding. These two types of listening can be coincided with the situations regarding Port Operations of both departments and Repair works;

2) Listen for details is required in case of Watchkeeping procedures and Radio communications;

3) Listen and predict is applied for all language situations of professional marine environment;

To summarize, situations 1, 2, 4 of Navigation department and situations 1,2 of engineering department require precise processing of information and application of strategies of listening for details. In contrast the rest of situations usually starts with the listening for main idea and alter to listening for details. The cadets should be trained to the $5^{\text {th }}$ type of listening, Listen and predict, they are to use contextual and situational cues in all situations. For instance, in case of hearing May Day signal he/she is to "switch on" listening for details; or when taking over the underway watch regardless of the department he/she shall listen to global understanding.

Every above mentioned field of Maritime English use aboard the ship comprises additional subskills of expressing problems, evaluating, awareness, reporting, discussion, solving and decision making. The exception is the commands to the helm and orders in the engine room which are supposed verbal confirmation and execution from the side of the seafarers. Thus the cadets should be learned to identify and use various types and strategies for the specific purposes listening.

The essential question for efficient learning and training the listening skills for special purposes is the material for this process. The suggested principles of material selection for Maritime English listening are: relevance, transferability/ applicability and task orientation (Morley, 2001). The principle of relevance allows holding the cadets attention and increase their motivation. Both content (information) and outcome (the nature of use of this info) of the chosen material are to be valid for them. The real profession situations are preferable. Transferability deals with relevance as it can be applied in real life as source of professional information or topic for social communication. This principle also enhances the learning process and cadets' motivation. The principle of task orientation allows Maritime English educators combine development of several skills, namely listening and solving problems, listening and summarizing information, interactive listening and negotiating. Such combinations of listening activities assist in forming of base and operational experiences of the cadets. They give the cadets opportunities for developing expectancies, enlarge their vocabulary and increase predictive power for future communicative situations. It should be noted that communicative situations aboard the ship are predictable only in the sphere of orders and commands during such operations as pilotage or mooring. The communicative situations of non-order nature (cargo operations, inspections, routine procedures) require a wide range of skills in listening and speaking.

The above mentioned principles for creating special purpose listening material together with the teaching of listening to the seafarers is possible by using CALL (Computer Assisted Language Learning) namely through the World Wide Web. The variety of authentic materials deems to increase motivation of the cadets, acquaint them with the diversity of accents, add interactive strategies to the classes and evoke the cadets' learning autonomy. The internet services are communication (electronic mail, newsgroup, Internet telephony and Internet fax), information retrieval (gophers, wais, file transfer protocol and veronica) and the World Wide Web (electronic commerce, information search and retrieval) (Turban, Rainer \& Potter, 2001). "Internet-based technology and more specifically digital stories promote L2 learning. They also present new linguistic forms, grammar, phrases, vocabulary and formulaic speech within a meaningful and structured context that supports comprehension of the narrative world" (Sejdi, 2017, p.3). The research data (Shen Lin, 2008) of using websites for 
developing listening skills have shown the overall improvement of required skills. The students stated the convenience of this recourse and increasing of autonomous learning strategies. They could improve other skills while they listened through websites, such as pronunciation, speaking, reading, vocabulary learning. (p. 8).The listening skills can be practiced via internet by watching YouTube videos, special maritime training videos (Seagull, Videotel) or any professional programs, listening to EFL podcasts and TED-talks. The visual contact improves the comprehension and holds the attention of the cadets. These resources are available on free of charge base.

YouTube is a Web 2.0 site, a kind of social media and the world's biggest online repository of videos which are created or generated, loaded and shared by users all over the world. The content of videos is diverse and variable, dealing with all aspects of human life and allowing people to participate in peer feedback through asynchronous interaction with other users. According to Ghasemi, Hashemi and Bardine (2011) the YouTube provides learners the opportunity to get more exposure to native language and different styles of spoken English by highlighting not only academic English but also its application in real-life contexts, incorporating accents, slang and much else. The cadets can acquire diverse spoken languages formal, neutral, informal and genres, presentations, lectures, streams. The authentic nature of YouTube videos undoubtedly benefits for selecting appropriate materials and achieving Maritime English learning outcomes. In case of multilingual crew comprehension of different types of accents is vital for safe operation of the ship.

The communicative approach of Maritime English learning process requires active participation of the cadets. The numerous videos on marine topics permit educators to create real context and encouraging language environment, training listening skills and enlarging vocabulary greatly, thus facilitating developing the cadets' specific purposes listening skills. For instance, VHF radio communication is essential for ship's operation and faces certain problems in the terms of accent comprehension or sound interferences. The YouTube search of this topic (https://www. youtube.com/results?search_query $=\mathrm{VHF}+$ communi- cation + at + sea) suggests both training videos and real VHF communication between the ships and stations with factual mode of delivery, interferences and speed of speech. The strategies for this type of task are equal to listening tape recording from the books with a pedagogical sequence. To start with, the "training stage" can be applied: the task is to listen and to get used to SeaSpeak without thorough comprehension. They have the opportunity to use the subtitles, change the speed of audio recording at early stages or to choose various cases of VHF communication. Later stages involve individual or pair comprehension tasks with the pre-listening (elicitation, brainstorming), on- listening (paraphrasing, note-taking, sequencing) and post listening (problem solving, summarizing, free practice as follow up to listening) activities or listening lesson can be of Task-based character with active interaction of the cadets in subgroups. The common sequence of such lesson is pre-task (introduction), task cycle (planning and report) and language focus (analysis and practice) with a huge variety of the tasks (Wilson, 2019). However, the strategies of listening for details are of the utmost importance in case of VHF Radio communication, SAR Operations or Emergencies. The cadets should be able to recognize the entire information When they lack some skills to infer the heard items (bottom-up strategies: recognizing language forms, patterns or items of vocabulary) they use their knowledge of the context to infer the meaning.

Conclusions. The importance of authentic listening by means of new technological tools such as the YouTube videos can hardly be overstated. The authentic videos are the vivid examples of natural speech thus creating the real language environment in the classrooms, enhancing the cadets' learning autonomy and raising language awareness. Moreover the systematic utilization of such listening material and practicing of active listening skills leads to reducing of misunderstandings aboard the ship. Further research is required for studying the difficulties the cadets face while listening, identifying the best working strategies in case of listening for details and creating a kind of database of marine videos which are available in the internet with further working out the methodological support.

\section{BIBLIOGRAPHY}

1. Winbow A. The importance of effective communication. International Seminar on Maritime English: March 20-22, 2002, Istanbul Technical University. URL: https://nanopdf.com/download/the-importance-of-effective-communication_pdf (Date of access: 02.09.2021).

2. Renukadevi D. The Role of Listening in Language Acquisition: the Challenges and Strategies in Teaching Listening. International Journal of Education and Information Studies. 2014. Vol. 4, No. 1. P. 59-63. URL: https://www.ripublication.com/ ijeisv1n1/ijeisv4n1_13.pdf(Date of access: 02.09.2021).

3. H Douglas Brown Language Assessment Principles and Classroom Practice. NY : Pearson Education, 2004.118 p. 
4. Herbert J. Walberg Teaching speaking, listening and writing. IAE: Educational Practices Series, 2004. $221 \mathrm{p}$.

5. Orr T. ESP for Japanese Universities: A Guide for Intelligent Reform. The Language Teacher Online. 1998. URL: https://jalt-publications.org/old tlt/files/98/nov/orr.html (Date of access: 02.09.2021).

6. Vishwanath Bite. Listening : An Important Skill and Its Various Aspects. The Criterion : An International Journal in English. Vol. 12, 2013. P. 2-9.

7. I. S. P. Nation, Newton J. Teaching ESL/EFL Listening and Speaking. Routledge : New York, 2009. 140 p.

8. Bakayeva G. E., Borysenko O. A., Zuyenok I. I. English of Specific Purposes. The National Curriculum for Universities. Kyiv: Lenvit, 2005. 120 p.

9. Wilson J.J. How to teach listening. England: Pearson Education limited, 2019. 192 p.

10. Morley M. Aural comprehension instruction: Principles and practices. Teaching English as a second or foreign language (3rd ed.). Boston: Heinle \& Heinle, 2001. P. 69-85

11. Vandergrift L., Goh, C. C. M. Teaching and Learning Second Language Listening: Metacognition in Actmi. New York : Routledge, 2012. $210 \mathrm{p}$.

12. Turban E. F., Rainer R. K., Potter R. R. Introduction to Information Technology. New York: Wiley Company. 2001. URL: https://www.academia.edu/330949/Introduction_to_Information_Technology (Date of access: 02.09.2021).

13. Sejdiu S. Are Listening Skills Best Enhanced Through the Use of Multimedia Technology. Digital Education Review. 2017. No. 32. URL: http://greav.ub.edu/der (Date of access: 02.09.2021).

14. Lin Shen, Winaitham Wichura, Saitakham, Kiattichai. The Use of Websites for Practicing Listening Skills of Undergraduate Students. A Case Study at Suranaree University of Technology. Thailand, 2008. URL: https://eric.ed.gov/?id=ED500929 (Date of access 02.09.2021).

15. Ghasemi B., Hashemi M., Bardine S. H. U Tube and language learning. Procedia-Social and Behavioural Sciences. 2011. Vol. 28. 63-67 pp. URL: https://www.sciencedirect.com/science/article/pii/S1877042811024529 (Date of access: 02.09.2021).

\section{REFERENCES}

1. Winbow A. (2002) The importance of effective communication. Proceedings of International Seminar on Maritime English (Istanbul, Turkey, March 20-22, 2002) Istanbul Technical University.

2. Renukadevi D. (2014) The Role of Listening in Language Acquisition: the Challenges and Strategies in Teaching Listening. International Journal of Education and Information studies, Vol.4, No1. pp. 59-63.

3. H Douglas Brown (2004) Language Assessment Principles and Classroom Practice. NY: Pearson Education. (in English)

4. Herbert J. Walberg (2004) Teaching speaking, listening and writing. IAE Educational Practices Series. (in English)

5. Orr T. (1998) ESP for Japanese Universities: A Guide for Intelligent Reform. The Language Teacher Online.

6. Vishwanath Bite (2013) Listening : An Important Skill and Its Various Aspects. The Criterion: An International Journal in English. Vol. 12. pp. 2-9

7. I. S. P. Nation, Newton J. (2009) Teaching ESL/EFL Listening and Speaking. Routledge : New York. (in English)

8. Bakayeva G. E., Borysenko O. A., Zuyenok I. I. (2005) English of Specific Purposes. The National Curriculum for Universities. Kyiv: Lenvit. (in English)

9. Wilson J.J. (2019) How to teach listening. England: Pearson Education limited. (in English)

10. Morley M. (2001) Aural comprehension instruction: Principles and practices. Teaching English as a second or foreign language (3rd ed.). Boston: Heinle \& Heinle. pp. 69- 85 (in English)

11. Vandergrift L., Goh C. C. M. (2012) Teaching and Learning Second Language Listening: Metacognition in Actmi. New York: Routledge. (in English)

12. Turban E.F., Rainer R.K., Potter R. R. (2001) Introduction to Information Technology. New York : Wiley Company. (in English)

13. Sejdiu S. (2017) Are Listening Skills Best Enhanced Through the Use of Multimedia Technology. Digital Education Review. Retrieved from: http://greav.ub.edu/der (accessed 02 Sept 2021).

14. Lin Shen, Winaitham Wichura, Saitakham Kiattichai (2008) The Use of Websites for Practicing Listening Skills of Undergraduate Students. A Case Study at Suranaree University of Technology. Thailand. (in English)

15. Ghasemi B., Hashemi M., Bardine S. H. (2011) U Tube and language learning. Procedia-Social and Behavioural Sciences. Retrieved from: https://www.sciencedirect.com/science/article/pii/S1877042811024529 (accessed 02 Sept 2021). 